\title{
Lake Qinghai Scientific Drilling Project
}

Lake Qinghai in the People's Republic of China covers $4400 \mathrm{~km}^{2}$ on the northeastern margin of the Tibetan Plateau ,at an elevation of $3194 \mathrm{~m}$ (Fig. 1). The lake is extremely sensitive to changes in climate because it lies in a critical transitional zone between the humid climate region controlled by the East Asian monsoon and the dry inland region affected by westerly winds. Three major atmospheric circulation systems affect its climate: (i) the winter monsoon, induced by Siberian high pressure and associated highlatitude ice cover, (ii) tropical moisture from low latitudes, carried by the East Asian summer monsoon, and (iii) climatic changes in the North Atlantic region, the effects of which are inferred to be transmitted via the westerlies. A study of drill cores from the lake and the surrounding area is critical for understanding the climatic, ecological, and tectonic evolution of the area, including the development of the East Asian monsoon system and its relationship to major global atmospheric circulation.

Lake Qinghai occupies a closed tectonic depression, or piggy-back basin, on the upper plate of a major, active thrust fault. The basin is bound to the north by the Qilian Mountains, which constitute the northeastern margin of the Tibetan Plateau. The lake basin thus is intimately related to the active tectonics of the Tibetan Plateau. Seismic-reflection data show that the lake sediments are tectonically deformed in some parts of the basin and largely undeformed in other parts, where they should record at least the timing of regional tectonism. The seismic surveys indicate that the shallow lake is underlain by northern and southern sub-basins and that the southern sub-basin contains a continuous stratigraphic sequence of unconsolidated sediments more than $700 \mathrm{~m}$ thick.

At an international workshop in Xining, China in October 2003, the Qinghai Drilling Project was planned to obtain a series of cores from at least four different sites, penetrating 200-700 $\mathrm{m}$ into the lake sediment and possibly reaching Pliocene or older strata. Other sites with shallower penetrations of 5-50 m were planned to target specific high-resolution climatic intervals in the Holocene and last several glacial cycles. The overall scientific objectives of the project are listed below.

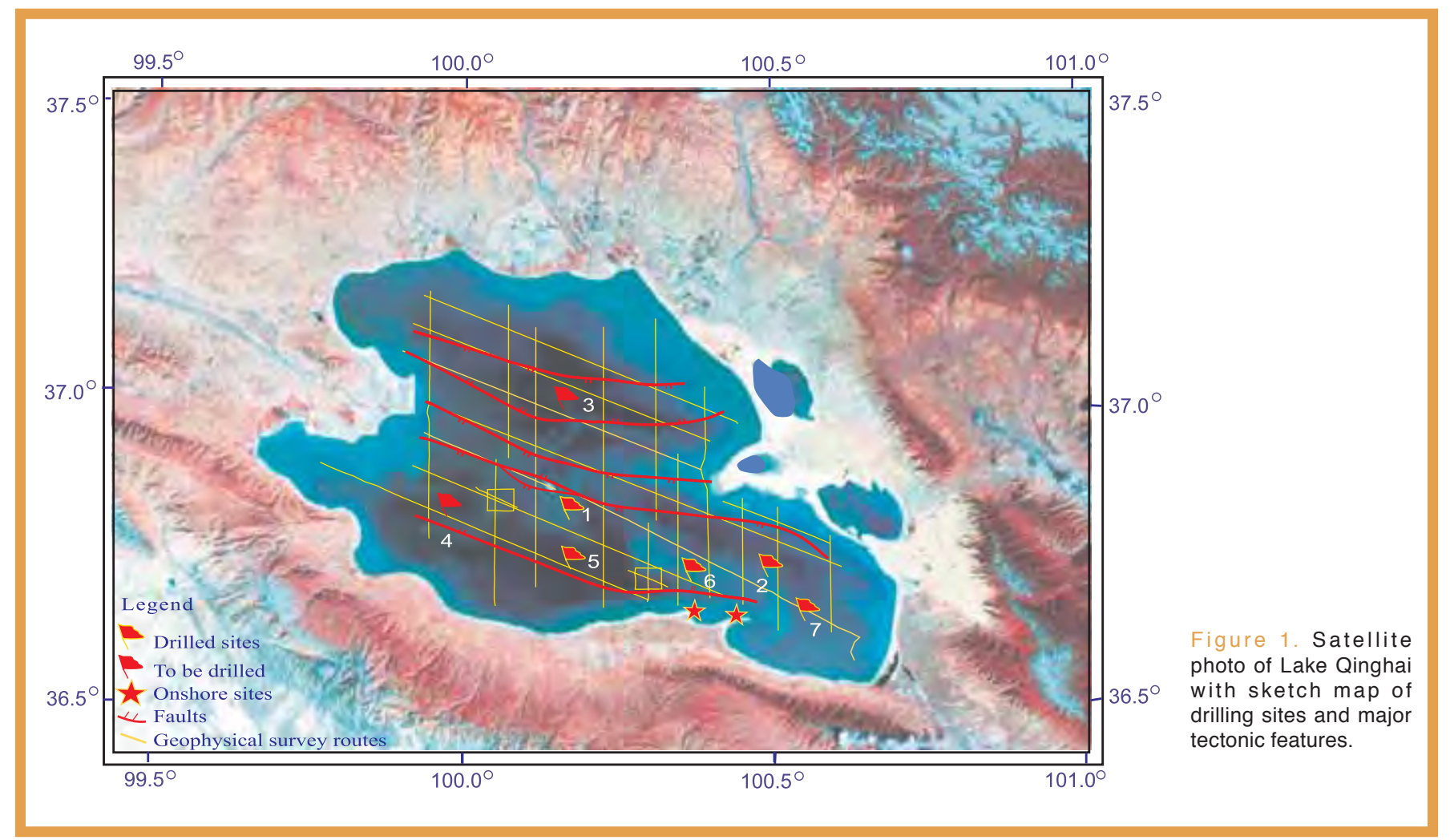




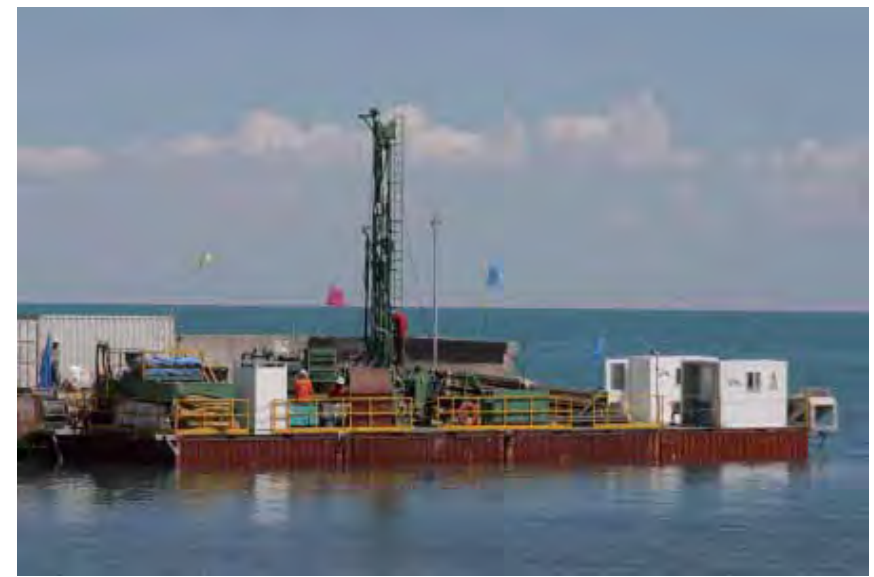

Figure 2. The GLAD800 drilling system towed away from the dock site for first coring.

- To obtain an improved understanding of the late Cenozoic environmental history of the Lake Qinghai region and the development of the East Asian monsoon climate

- To understand the Late Cenozoic tectonic evolution of the Lake Qinghai basin and the growth of the northeastern margin of the Tibetan Plateau and its effects on regional climate

- To correlate Lake Qinghai environmental records with other regional and global paleoclimatic records to obtain a better understanding of the connection between regional climatic change, the development of the East Asian monsoon system, prevailing westerlies, and, ultimately, the evolution of global climate

After several weeks of delay caused by poor weather and a regional outbreak of bird flu, drilling operations began in late July 2005 and continued to early September. The drilling was conducted from a barge with the Global Lake Drilling $800 \mathrm{~m}$ (GLAD800) coring system (Fig. 2), the modular ICDP drilling platform and drilling system operated by the Consortium for Drilling, Observation and Sampling of the Earth's Continental Crust (DOSECC). DOSECC's coring operations were supported by the Qinghai Geology Survey and scientists from the Xi'an Institute of Earth Environment of the Chinese Academy of Sciences (IEECAS, Fig. 3). The sediment cores were described initially onboard by observing through the plastic core liners and examining core-catcher samples. The maximum 1.5-m-long core segments were scanned for petrophysical properties with a GEOTEK instrument at a shore base that was occupied throughout the drilling operations.

In total, 324 core runs for $548 \mathrm{~m}$ of drilling acquired $323 \mathrm{~m}$ of core at an average recovery rate of $59 \%$ (Table 1). The upper few tens of meters of sediment were mainly gray clay and silty clay. Core recovery was excellent in this upper part of the lake bed, and these cores will serve for the planned high-resolution study of climatic changes extending through much of the last glaciation. The sediment below the clay-rich upper section was mainly rather fine-grained, unconsolidated sand with only a few clayey layers. The character of

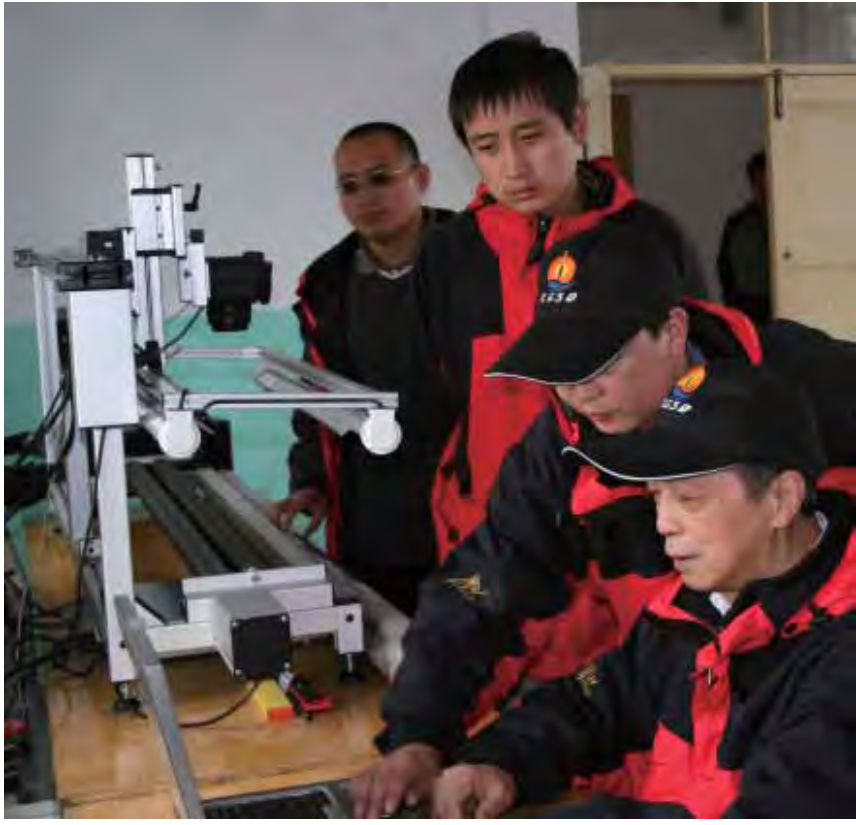

Figure 3. ICDP's optical core scanning system in use at the shore base.

these sandy units plus the persistent rough wind and wave conditions experienced during the drilling operation greatly hindered the recovery of good cores. The principal investigators thus decided to postpone the proposed 700-m drilling for a future campaign and to focus on obtaining high-quality, overlapping cores of the upper $30-50 \mathrm{~m}$ of relatively finegrained sediment at several sites (Fig. 1). Hole $2 \mathrm{C}$ penetrated the deepest $(114.9 \mathrm{~m})$, and the cores from this site may provide paleoenvironmental information through the late Pleistocene.

Concurrently with offshore drilling, an onshore site was drilled successfully on Erlang Jian on the southeastern shore of the lake (Fig. 1) using Chinese equipment (Fig. 4). The drill rig was deployed to its maximum drillstring capacity, allowing coring down to $1108.9 \mathrm{~m}$, with an average recovery of more than $90 \%$ (Table 1, Fig. 5). Comparison to field exposures suggests that the lowermost sediment recovered has a maximum age of late Miocene. The onshore drilling was conducted by the Qinghai Geology Survey, in collaboration with the IEECAS. Encouraged by the initial success,

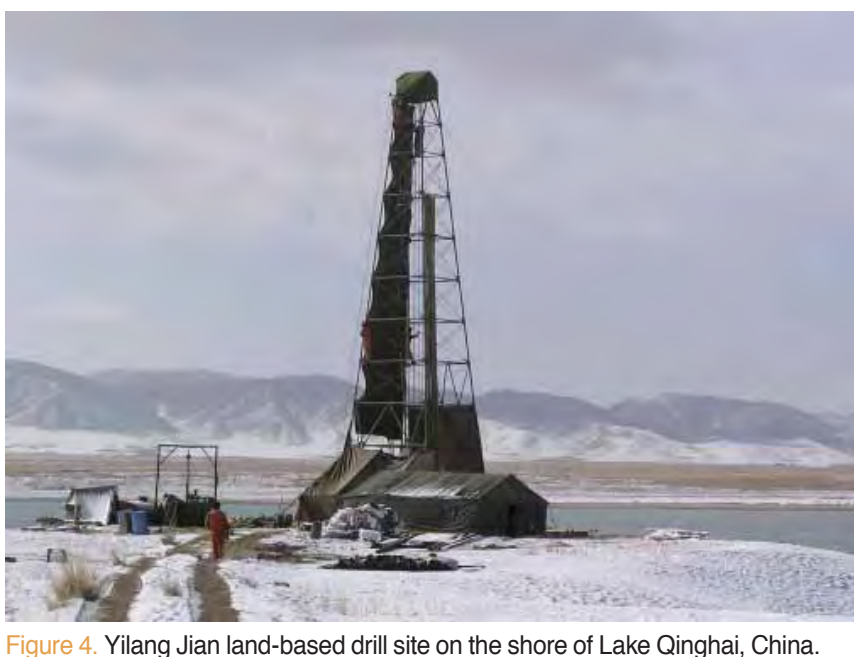




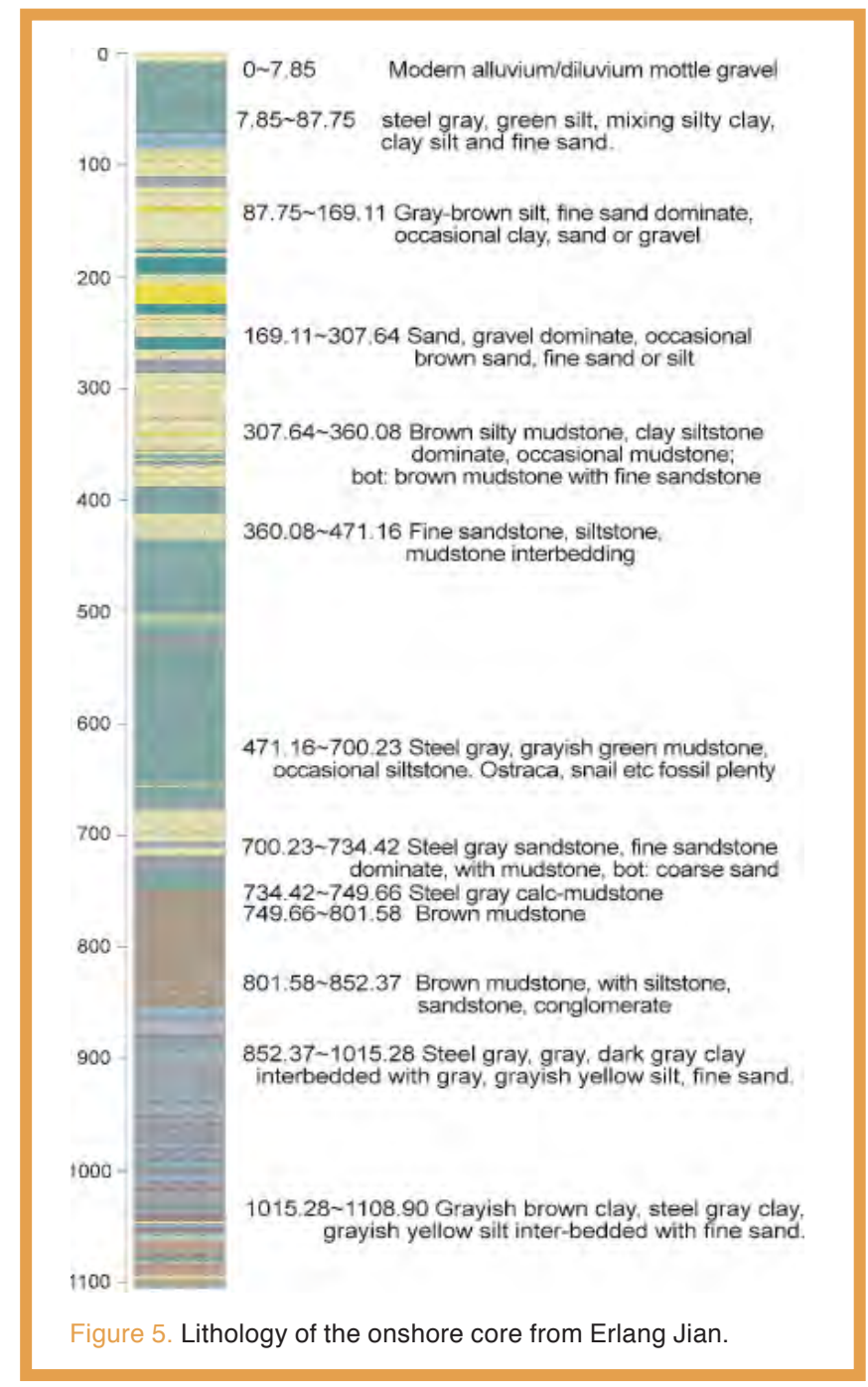

the team drilled a second borehole at Yilang Jian and retrieved another $628.5 \mathrm{~m}$ of core.

All drill cores were shipped in refrigerated trucks to the IEECAS in Xi'an, China for storage at $2-5^{\circ} \mathrm{C}$. So far, about sixty scientists from China, Japan, Europe, and North America have expressed interest in participating in upcoming studies. The principal investigators Z. An, S.M. Colman, G. Haug, P. Molnar, and T. Kawai and the science team members are planning a science coordination and sampling meeting as soon as samples can be made available after opening and fully describing the cores.

\section{Acknowledgements}

About 500 scientists, engineers, and technicians from the People's Republic of China and abroad worked at and visited the drilling sites, mainly from the Chinese Academy of Sciences, the Ministry of Science and Technology of China, the National Science Foundation of China, the China Meteorological Association, the ICDP, and several universities and research organizations, as well as local governments. China Central Television and other TV stations and newspapers gave enthusiastic attention to this scientific research. They are all thanked for their contributions.
Table 1: Drill holes, core recovery, and statistics of coring.

\begin{tabular}{|c|c|c|c|}
\hline \multicolumn{4}{|c|}{ Offshore cores } \\
\hline Hole & Drilled $\mathrm{m}$ & Cored $\mathrm{m}$ & Recovery \\
\hline $2 \mathrm{~A}$ & 18.8 & 18.2 & $97 \%$ \\
\hline 2B & 3.0 & 2.9 & $98 \%$ \\
\hline $2 \mathrm{C}$ & 114.9 & 76.8 & $67 \%$ \\
\hline $2 \mathrm{~F}$ & 25.2 & 23.5 & $93 \%$ \\
\hline $1 \mathrm{~A}$ & 93.0 & 39.7 & $43 \%$ \\
\hline $1 \mathrm{~F}$ & 20.2 & 19.3 & $95 \%$ \\
\hline $1 \mathrm{G}$ & 20.4 & 17.6 & $86 \%$ \\
\hline $5 \mathrm{~A}$ & 26.7 & 14.0 & $53 \%$ \\
\hline $5 B$ & 36.6 & 16.9 & $46 \%$ \\
\hline $6 \mathrm{~A}$ & 50.6 & 23.4 & $46 \%$ \\
\hline $6 \mathrm{C}$ & 27.6 & 17.5 & $63 \%$ \\
\hline $7 A$ & 51.4 & 24.1 & $47 \%$ \\
\hline 7B & 59.4 & 29.3 & $49 \%$ \\
\hline Total & 547.9 & 323.3 & $\begin{array}{c}\text { Average } \\
59 \%\end{array}$ \\
\hline \multicolumn{4}{|c|}{ Onshore cores } \\
\hline 1 & 1108.9 & & $>90 \%$ \\
\hline 2 & 628.5 & & $>90 \%$ \\
\hline
\end{tabular}

\section{Authors}

An Zhisheng, Institute of Earth Environment, CAS, 10 Fenghui South Road, Xi'an High-Tech Zone, Xi'an, 710075, People’s Republic of China, e-mail: anzs@loess.llqg.ac.cn.

Ai Li, Institute of Earth Environment, CAS, 10 Fenghui South Road, Xi'an High-Tech Zone, Xi'an, 710075, People's Republic of China.

Song Yougui, Institute of Earth Environment, CAS, 10 Fenghui South Road, Xi'an High-Tech Zone, Xi'an, 710075, People's Republic of China.

Steven M. Colman, Large Lakes Observatory \& Department of Geological Sciences, University of Minnesota-Duluth, RLB, 2205 East 5th Street, Duluth, Minn. 55812, U.S.A.

\section{Related Web Link}

http://qinghai.icdp-online.org

\section{Figure Credits}

Figure 2 by Ronald Conze (ICDP).

All other figures courtesy of the Lake Qinghai Drilling Project. 